\title{
Writing Ability of Paragraph Arguments of Students Who Have High Reading Interest in the Group Using the Quantum Writing Method
}

\author{
Ika Nurjanah ${ }^{1}$, Biner Ambarita ${ }^{2}$, Abdul Muin Sibuea ${ }^{2}$ \\ ${ }^{1}$ Master Student in Indonesia Language, Postgraduate Program, State University of Medan (Unimed), Indonesia \\ ${ }^{2}$ State University of Medan (Unimed), Indonesia \\ izzah64@yahoo.co.id
}

\begin{abstract}
This study discusses about writing ability of paragraph arguments of students whose have high reading interest in the group using quantum writing method. The location of this study is MAS of Academic School of Islamic Education 2017/2018. The result shows that the ability to write paragraph arguments for students who are taught using higher quantum writing. The ability to write paragraphs in arguments for students with high reading interest is more suitable to be taught using the quantum writing method
\end{abstract}

Keywords : writing ability; reading interest; group; quantum writing

\section{Introduction}

The low level of vocabulary mastery, lack of giving writing exercises, inaccurate learning methods and the limitations of effective instructional learning media are the causes of the learning objectives of writing not achieved. Another important factor is from the students themselves, namely the low interest of students in writing lessons. This condition is exacerbated by the lack of reading interest of the students. Therefore, some people assume that writing is the most difficult skill to master compared to other language skills. Students often have difficulty expressing their ideas or ideas in writing. They experience confusion when they start writing. One paragraph with another paragraph often does not have a good unity of ideas and coherence so the direction of the goal is unclear.

This was confirmed by the results of the ranking study (Cahyani, 2002: 84) on language skills, which appeared to be a significant comparison, namely listening skills $45 \%$, speaking $30 \%$, reading 16\%, and writing 9\%. In addition, Fitriani (2003: 98) in her research showed that writing activities were still considered a boring, difficult, time-consuming and thoughtful activity. This could be seen from some students who still find it difficult to find ideas in writing so students do not often feel reluctant when assigned to write essays. As a result, the ability of students to write was low.

Conditions like this must be addressed immediately. One of them is by changing the learning pattern that has been going on one direction with the teacher as the subject and students as objects to the two-way learning model. In order to grow the desire of students in the learning process of writing paragraph arguments, a teacher is expected to be able to present various methods, models, techniques, strategies, and media. Teachers must be creative in choosing learning methods, because it is a thing that is able to realize stimuli in developing students' intelligence and experience. As an alternative problem solving, the researchers are interested in using the quantum writing method in writing lessons in the argumentation class. Because in the application of the debate method and the quantum writing method, the students will play an active role in taking part in writing lessons in the argumentation level. In addition, the stages contained in the quantum writing method also make it easier for students to absorb the information provided by the teacher in relation to writing paragraph arguments.

The quantum writing method makes students more confident, and recognizes the potential that exists in themselves. Learning with the quantum writing method presents a 
concept by linking subject matter to context. The material is used as well as the relationship with how a person learns. Learning material will increase meaning if students learn the material presented through the context of their lives and find meaning in the learning process, so that learning will be more enjoyable.

\subsection{Writing Skills}

\section{Review of Literature}

Writing skills are one of the language skills that are the goal of every language lesson in school. Writing skills are everyone's rights and can be learned. Writing is a development process. If someone wants to have skill at writing, they have to practice a lot. In conjunction with language skills, sensitivity is increasingly sharpened to mistakes both spelling, structure, and vocabulary.

Compared to other language skills, writing skills are skills that some consider to be the most difficult skills even if native speakers of the language are concerned. This is because the ability to write requires mastery of various linguistic elements and elements from outside the language in accordance with the contents of the writing. And these elements must be intertwined to produce coherent and coherent writing (Nurgiantoro 2001: 296).

Writing skills is a process of growth through many exercises to master writing skills is not enough just to learn grammar and learn the knowledge of writing, even if only memorize the definitions or terms contained in the field of corals.

\subsection{Argument Paragraph}

Kosasih (2003: 50) "Understanding the argument means reason". Argumentation means giving strong and convincing reasons. Thus, the paragraph argumentation is a paragraph that presents strong, convincing reasons, examples and evidence. Reasons, evidence and the like is used by writers to influence readers so that they agree to opinions, attitudes, or beliefs. Gorys Keraf (2010: 3), "Argumentation is a form of rhetoric that seeks to influence the attitudes and opinions of others, so that they believe and ultimately want to act in accordance with what is desired by the author". Through the fabrication of argumentation, the author tries to assemble the facts in such a way that he is able to show whether an opinion or a particular thing is true or not.

Wagiran and Doyin (2005: 55) "Argumentation is to persuade or convince the reader by describing the reasons, facts, evidence of an opinion, the idea of solving a problem". Paragraph development begins with expressing a public opinion which is the subject of thought then explanatory sentences which are facts that can convince the opinion. Cahyani (2002: 5) states that "Arguments come from the word argument which means reason". Argumentation is one type of paragraph which expresses an idea, opinion, or attitude accompanied by reasons so that the reader understands and justifies it, to strengthen the reason, the author can include supporting data in the form of facts, examples, observations, and others.

Arguments are divided into two types, namely inductive argumentation and deductive argumentation. Inductive argumentation is a thought process that starts from one or a number of individual phenomena to derive a conclusion. Inductive argumentation is a process of thinking of things that are specific to things that are general in nature (Keraf: 2010: 45). Deductive argumentation is a process or reasoning that departs from something that already exists towards a new proposition in the form of a conclusion. A deductive argument is a process of thinking and something of a general nature to a specific matter (Keraf 2010: 57). 
The difference in proof of argumentation with persuasion, narration, exposition, and description according to Hardiyanto (2003: 15) contains several things, namely (1) writing arguments must contain the truth to change people's attitudes and beliefs about the topic being argued. To show the truth, a writer must compile the correct facts, (2) the author must try to avoid any terms that can cause certain prejudices, (3) the author must limit the meaning of the terms to be used, so that the possibility of opinion discrepancies can be minimized because differences in understanding, and (4) the author must determine precisely the point of disagreement that will be argued. This step is an important step, because, every analysis presented must clearly show the difference.

\subsection{Reading Interest}

Interest is one of the psychological factors that causes students to read. Interest can encourage an individual to give stimulus to an activity that is carried out to achieve a goal to be achieved. Interest arises when individuals are attracted to something they consider something that is for themselves and can meet needs they want. According to Slamet, (2008: 180) states that interest is a sense of preference and sense of attachment to a thing or activity, without being told.

Furthermore, Sabri (2007: 84) interest is a tendency to always pay attention to and remember things continuously.Saleh, (2008: 261) that "someone's interest in something is a tendency of a high heart, passion or desire for something. If students see something that will provide benefits, they will gain satisfaction and students will interested in this. According to Shah (2004: 136) "Interest is desire and enthusiasm high faith or great tendency towards something. Interest so far understood and used by people can affect the quality of student learning outcomes. "Whereas according to Sobur (2003: 246) said "In this case of course someone who has an interest in a field will be easier to learn about the field. Even if someone is able to learn something, but if they do not have interest they will not be able to follow the learning process."

Drajat says that Children's interests can arise from various sources including the development of instincts, intellectual functions, the influence of the environment, experience, habits and education. Therefore someone's interest must be fostered and directed towards achieving the desired goals, especially in learning. To increase someone's interest, education experts argue that the most effective way to increase interest is to utilize existing interests in students. For example students are interested in car racing, before teaching accelerating material need to tell a little about ongoing car racing, only gradually directed to the actual subject matter. In addition, it can also be by forming new interests, namely by giving information to students about relationships a teaching material.

From the various theories described above it can be understood that interest is basically one of the driving aspects in a person in realizing a desire or need. Interest must be realized in the form of various efforts so that the intended purpose can be achieved. Furthermore, according to the general understanding of reading can be concluded that reading is a complex activity that includes physical and mental. Physical activity related to reading is eye movement and visual acuity. Mental activities include memory and understanding.

Reading is important for humans. By reading, a person can stimulate his brain to think creatively and systematically, expand and enrich insight, and form superior and competitive personalities. Great influence on reading, because if the reading material is not in accordance with the interests of students, students will not read with as good as possible because there is no attraction for him. However, if the reading material attracts students' interest, the reading 
material will be easier to learn and be stored by the students themselves so that students can easily re-pour when tested or tested which ultimately increases student learning achievement According to Hurlock, quoted by Galuh, the characteristics of growth and development of interest in children are as follows:

1. Interest in growing along with physical and mental development

2. Interest depends on the child's readiness and maturity

3. Interest depends on learning opportunities

4. Cultural influences

5. Interest related to emotional.

According to Syaiful Rijal quoted by Zaen, it was stated that a child who has a high reading interest has the following characteristics:

1. Always willing to read

2. Always excited when reading

3. Having habits and continuity in reading

4. Take advantage of every opportunity by reading

5. Have a reading book

6. Search for reading material, both in the library and elsewhere

7. Have goals when reading

8. Take notes or mark important things in reading

9. Having an awareness that reading means learning

10. Discuss the reading

The following are some of the objectives of reading activities, namely:

1. Reading is a pleasure not to involve a complicated thought.

2. Reading to increase knowledge and insight.

3. Reading to be able to do a job or profession.

According to experts According to experts reading Steve Stahl which was quoted by Jhon W. Santrock the purpose of instructional reading should be able to help students to: (1) Identify words automatically (2) Understand text (3) Motivated to read and appreciate reading.

\section{Research Method}

The location of this study was MAS of Academic School of Islamic Education 2017/2018. As for the reason the researchers chose the location as follows:

a. The location of the school is affordable in terms of distance, time, and cost in taking data.

b. The school has facilities and qualities that support the implementation of research

c. The school has a good teaching and learning situation that makes it possible to do research.

d. Research Time of this research would be held for two months in the even semester 2017/2018 Academic Year.

According to Sudjana (2005: 5), "Population is the totality of all values that may be the result of counting or measurement, quantity, and quality of certain characteristics regarding a complete set of objects and methods who want to learn its properties." While Arikunto (2005: 130) says that, "Population is the whole subject of research." Similarly, Sugiono (2008: 117) says that, "Population is the whole object / subject set by the study to be studied."

Based on this opinion, the author adheres to Sugiono's opinion. Then the population in this study were all students of class X MAS of Academic School of Islamic Education 2017/2018 which numbered as follows: 
Table 1. Population of Class X MAS of Academic School of Islamic Education 2017/2018

\begin{tabular}{|c|c|c|}
\hline NO & Class & The Number of Students \\
\hline 1 & X1 & 30 Orang \\
\hline 2 & X2 & 30 Orang \\
\hline 3 & X3 & 30 Orang \\
\hline
\end{tabular}

\section{Discussion}

Ability to Write Paragraphs of Student Arguments Using Quantum Writing Learning Methods Furthermore, the ability to write paragraph arguments for students using the quantum writing learning method obtained the highest tertiary value of 90 and the lowest value of 60 with an average value of 78.80 and a standard deviation of 6.99. Then the median value (Me) 78.6 mode (Mo) 78.3 and variance $\left(\mathrm{S}^{2}\right)$ 48.9. The summary calculation of the data can be seen in the following table.

Table 2. Frequency Distribution Writing Ability Argumentation Paragraph Using the Quantum Writing Method

\begin{tabular}{|c|c|c|c|}
\hline No & Interval Class & Fabsolut & Frelatif $_{(\%)}$ \\
\hline 1 & $60-66$ & 2 & $6,7 \%$ \\
\hline 2 & $67-73$ & 2 & $6,7 \%$ \\
\hline 3 & $74-80$ & 15 & $50 \%$ \\
\hline 4 & $81-87$ & 9 & $30 \%$ \\
\hline 5 & $88-94$ & 2 & $6,6 \%$ \\
\hline \multicolumn{2}{r|}{ Total } & 30 & $100 \%$ \\
\hline
\end{tabular}

Based on the table that the value of the ability to write paragraph arguments of students who are taught by the quantum writing method is known that 4 people or $13.4 \%$ are below the average score and as many as 26 people or $86.6 \%$ are above the average score. The following is the distribution of the ability to write paragraphs in student arguments.

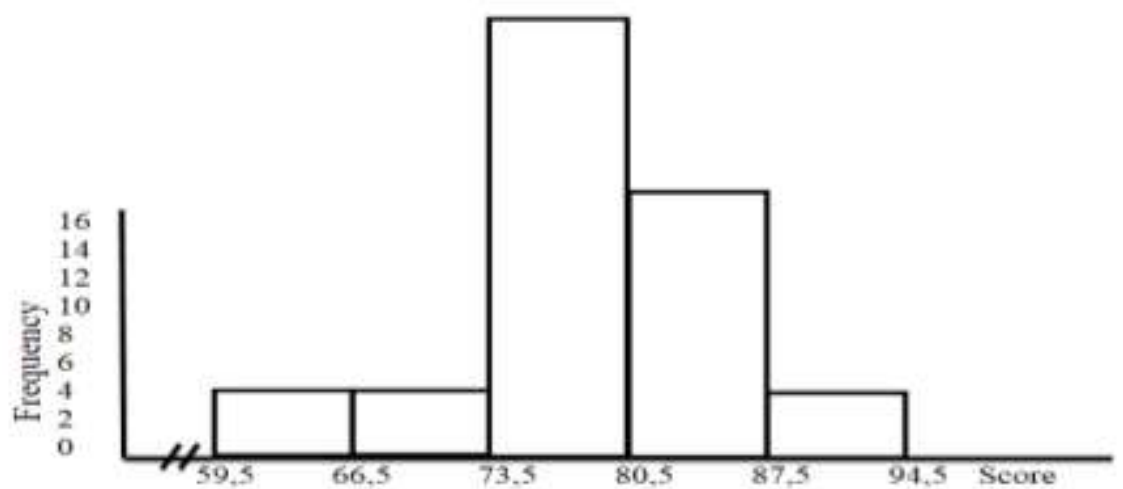

Figure 1. . Histogram Value Writing Ability Test Argument Paragraph Using the Quantum Writing Method.

Based on the data obtained by the value of the test of the ability to write paragraph arguments students have high reading interest taught by using the quntum writing method the highest value is 90 and the lowest value is 76 with an average value of 83.47 and a standard deviation of 3.64. Then the median value (Me) 84, mode (Mo) 84 and variance (S2) 13.27. The summary calculation of the data can be seen in the following table. 
Table 3. Frequency Distribution of High Reading Interests in Learning Groups Using the Quantum Writing Method

\begin{tabular}{|c|l|c|c|}
\hline No & Interval Class & Fabsolut & Frelatif (\%) \\
\hline 1 & $76-78$ & 2 & $13,3 \%$ \\
\hline 2 & $79-81$ & 2 & $13,3 \%$ \\
\hline 3 & $82-84$ & 6 & $40 \%$ \\
\hline 4 & $85-87$ & 3 & $20 \%$ \\
\hline 5 & $88-90$ & 2 & $13,4 \%$ \\
\hline \multicolumn{2}{|c|}{ Total } & 15 & $100 \%$ \\
\hline
\end{tabular}

Based on the table above, that the average value of the ability to write paragraph arguments for students who have a high reading interest in the quntum writing method group is that students who have the highest reading interest are in the 88-90 interval class with 2 students or $13.4 \%$. While students whose values are below the average number 0 or $0 \%$. Students with the above values above score an average of 15 people or $100 \%$. The following is the distribution of arguing paragraph writing skills of students who have high reading interest in the quntum writing method group presented in the form of a diagram in the figure 2.

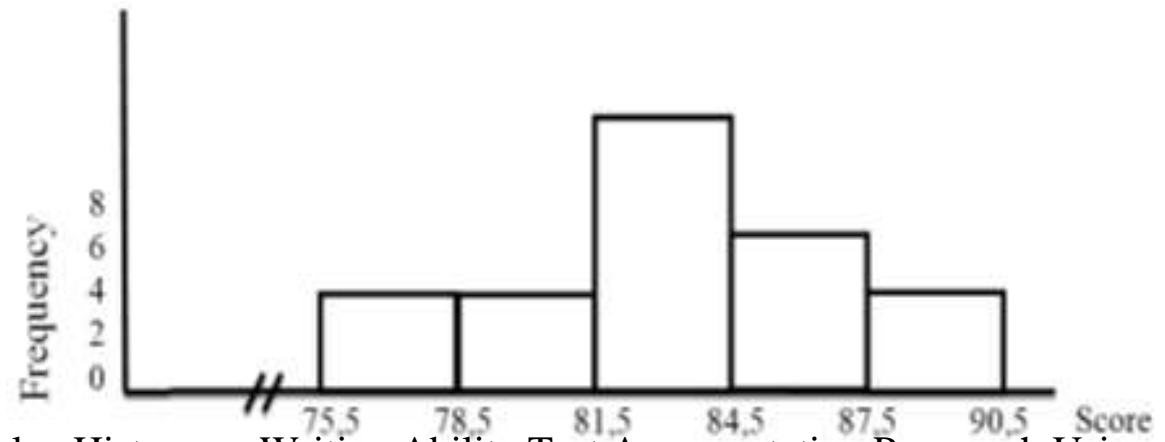

Figure 2. Value Histogram Writing Ability Test Argumentation Paragraph Using Quantum Writing Method that has High Reading Interest

\section{Normality Test}

a. Data Normality Test Learning Method

Table 4. Results of Testing the Normality of the Learning Method Data

\begin{tabular}{|l|l|r|c|c|c|}
\hline No & \multicolumn{1}{|c|}{ Group } & N & Lo & Lt(0,05) & Conclusion \\
\hline 1 & $\begin{array}{l}\text { Ability to Write Student } \\
\text { Arguments in Groups Using } \\
\text { the Quantum Writinng } \\
\text { Method }\end{array}$ & 0,0867 & 0,161 & Normal \\
\hline
\end{tabular}

\section{b. Data Normality Test For Reading Interest}

Analysis and calculation of the results of normality test data for reading interest are summarized in the following table.

Table 5. Test Results for Normality of Reading Interest

\begin{tabular}{|l|l|c|c|c|c|}
\hline No & \multicolumn{1}{|c|}{ Group } & $\mathbf{N}$ & \multicolumn{1}{c|}{$\mathbf{L}_{\mathbf{o}}$} & $\mathbf{L t}(\mathbf{0 , 0 5})$ & Conclusion \\
\hline $\mathbf{1}$ & $\begin{array}{l}\text { Interest in reading students } \\
\text { in the quantum writing } \\
\text { method }\end{array}$ & $\mathbf{3 0}$ & 0,0867 & 0,161 & Normal \\
\hline
\end{tabular}


Based on the table above, for students' reading interest in the debate method, $\mathrm{L}_{\text {hitung }}=$ 0.0974 is obtained. With $\mathrm{N}=30$ and the real level $\alpha=0.05$, then the critical value through the Liliefors test is obtained by $\mathrm{L}_{\text {tabel }}=0.161$. So obtained $\mathrm{L}_{\text {hitung }}<\mathrm{L}_{\text {tabel }}(0.0974<0.161)$ so that the variable $\mathrm{X}$ data is normally distributed.

Based on the table above, students' reading interest in the quantum writing method is obtained by $\mathrm{L}_{\text {hitung }}=0.0867$. With $\mathrm{N}=30$ and the real level $\alpha=0.05$, then the critical value through the Liliefors test is obtained by Ltabel $=0.161$. So it is obtained $\mathrm{L}_{\text {hitung }}<\mathrm{L}_{\text {tabel }}(0.0867$ $<0.161$ ) so that the data variable $\mathrm{Y}$ is normally distributed.

The table shows the results of the calculation of the normality test of students' interest in reading the ability to write paragraph arguments taught by the debate learning method with a value of $\mathrm{L}_{0}=0.0974$, while $\mathrm{L}_{t}=0.161$ at a significant level of 0.05 . Thus $\mathrm{L}_{0}<\mathrm{L}_{t}$ can be concluded that the data on reading interest is the ability to write paragraphs of arguments that are taught with normal distributed debate methods.

The results of the calculation of the normality test of students' reading interest are the ability to write paragraph arguments taught with the quantum writing learning method with a value of $\mathrm{L}_{0}=0.0867$, while $\mathrm{L}_{t}=0.161$ at a significant level of 0.05 . Thus $\mathrm{L}_{0}<\mathrm{L}_{t}$ can be concluded that the data is the ability to write paragraph arguments taught by the quantum writing method with normal distribution.

\section{c. Data Normality Test of Learning Methods and Reading Interests}

Analysis and calculation of the results of normality test data for learning methods and reading interest are summarized in the following table.

Table 6. Test Results for Data Normality of Learning Methods and Reading Interests

\begin{tabular}{|l|l|l|l|l|l|}
\hline No & \multicolumn{1}{|c|}{ Group } & N & $\mathbf{L}_{\mathbf{o}}$ & $\mathbf{L}_{\mathbf{t}}(\mathbf{0 , 0 5})$ & Conclusion \\
\hline $\mathbf{1}$ & $\begin{array}{l}\text { The ability to write paragraph } \\
\text { arguments for students has high } \\
\text { vocabulary in the quantum } \\
\text { writing learning method }\end{array}$ & $\mathbf{1 5}$ & 0,1372 & 0,220 & Normal \\
\hline $\mathbf{2}$ & $\begin{array}{l}\text { The ability to write paragraph } \\
\text { arguments for students has a } \\
\text { low vocabulary in the quantum } \\
\text { writing learning method }\end{array}$ & $\mathbf{1 5}$ & 0,1814 & 0,220 & Normal \\
\hline $\mathbf{3}$ & $\begin{array}{l}\text { The ability to write paragraphs } \\
\text { in student arguments has a high } \\
\text { vocabulary in the debate } \\
\text { learning method and quantum } \\
\text { writing }\end{array}$ & $\mathbf{3 0}$ & 0,0867 & 0,161 & Normal \\
\hline $\mathbf{4}$ & $\begin{array}{l}\text { The ability to write paragraph } \\
\text { arguments for students has a } \\
\text { low vocabulary in the debate } \\
\text { learning method and quantum } \\
\text { writing }\end{array}$ & $\mathbf{3 0}$ & 0,1387 & 0,161 & Normal \\
\hline
\end{tabular}


Table 7. Summary of Homogeneity Test Results between Sample Interests in Reading Groups Using the Quantum Writing Method

\begin{tabular}{|l|l|l|l|l|l|}
\hline NO & Sample & $\begin{array}{l}\text { Variance } \\
(\mathrm{S})\end{array}$ & $\mathrm{F}_{\text {hitung }}$ & $\mathrm{F}_{\text {tabel }}$ & Coclusion \\
\hline 1 & High Reading Interest & 3,64 & 1,76 & 2,39 & Homogeneous \\
\hline 2 & Low Reading Interest & 6,42 & & \\
\hline
\end{tabular}

Based on the table it can be seen that the skills of writing paragraph arguments in groups of students who have high and low reading interest with the Quantum Writing method obtained $F_{\text {hitung }}=1.76$ and $F_{\text {tabel }}=2.39$ at a significant level $\alpha=0.05$. The calculation results state that $F_{\text {hitung }}<\mathrm{F}_{\text {tabel }}$ means that the skill of writing paragraph arguments of students who have high and low reading interest uses the Quantum Writing method to have a homogeneous variance.

The introduction of the hypothesis to the skills of writing paragraph arguments and reading interest was carried out using the method of abalysis of variance in two lines (Anava) at a significant level of $\alpha=0.05$ and followed by the Scheffe test.

Rank the research results data can be seen in the following table.

Table 8. Summary of Research Data

\begin{tabular}{|c|c|c|c|}
\hline \multirow{2}{*}{\multicolumn{2}{|c|}{ Reading Interest }} & Learning Method & Total \\
\hline & & Quantum Writing & \\
\hline \multirow{5}{*}{ High } & $\mathrm{N}$ & 15 & 30 \\
\hline & $\sum x$ & 1.252 & 2459 \\
\hline & $\sum x^{2}$ & 104.686 & 201945 \\
\hline & $\chi$ & 83,47 & 81,97 \\
\hline & $S^{2}$ & 13,27 & 22,97 \\
\hline \multirow{5}{*}{ Low } & $\mathrm{N}$ & 15 & 30 \\
\hline & $\sum x$ & 1.112 & 2352 \\
\hline & $\sum x^{2}$ & 83.014 & 186018 \\
\hline & $\mathrm{x}$ & 74,13 & 78,40 \\
\hline & $S^{2}$ & 41,27 & 76,79 \\
\hline \multirow{5}{*}{ Total } & $\mathrm{N}$ & 30 & 60 \\
\hline & $\sum x$ & 2364 & 4811 \\
\hline & $\sum x^{2}$ & 187700 & 389645 \\
\hline & $\mathrm{x}$ & 78,80 & 80,18 \\
\hline & $S^{2}$ & 54,54 & 99,76 \\
\hline
\end{tabular}

\section{Conclusion}

The ability to write paragraph arguments for students who are taught using higher quantum writing. The ability to write paragraphs in arguments for students with high reading interest is more suitable to be taught using the quantum writing method. 
Budapest International Research and Critics in Linguistics and Education (BirLE) Journal

Volume 2, No 2, May 2019, Page: 268-277

e-ISSN: 2655-1470 (Online), p-ISSN: 2655-2647 (Print)

www.bircu-journal.com/index.php/birle

emails: birle.journal@gmail.com

birle.journal.qa@gmail.com

\section{References}

Akhaidah, Sabarti dkk. 1998. Pembinaan Menulis Bahasa Indonesia. Jakarta: Erlangga.

Alwasilah, A. Chaedar. 2001. Politik Bahasa dan Pendidikan.Bandung: Remaja Rosdakarya.

Alwasilah,A. Chaedar \& Senny Suzanna. 2001.Pokoknya menulis: Cara baru menulis dengan metode kolaborasi. Bandung: Kiblat Buku Utama.

Arifin, Zaenal. 2009. Evaluasi pembelajaran. Bandung: PT. Remaja Rosdakarya.

Arifin, Zaenal., Tasai, Amran. 2009. Cermat Berbahasa Indonesia Jakarta: Akademika Pressindo.

Arikunto Suharsimi. 2005,Manajemen Penelitian, Jakarta: Rineka Cipta.

......., 2002, Prosedur Penelitian: Suatu Pendekatan Praktek: Jakarta, Rineka Cipta. 2012. Dasar-Dasar Evaluasi Pendidikan. Jakarta: Bumi Aksara

Arsjad, Maidar G dan Mukti US. 2001. Pembinaan Keterampilan Berbicara Bahasa Indonesia. Jakarta: Erlanga.

Brown, Douglas, H. 2007. PrinsipPembelajaran dan PengajaranBahasa Edisi kelima. Hak cipta.

Cahyani, Isah. 2002. Model Proses Pembelajaran Menulis. Jurnal Kajian Bahasa dan Sastra Indonesia. $84-92$.

2002. Pembelajaran Menulis Argumentasi Berbasis Life Skill (Kecakapan Hidup). Jurnal Kajian Bahasa dan Sastra Indonesia.

Depdiknas. 2006 No 22 Tahun 2006 Tentang Standar Isi. Jakarta: Depdiknas.

Djamarah, Saiful Bahri dan Aswan Zain. 2010. Strategi Belajar Mengajar. Jakarta: Rineka Cipta.

Djiwandono, Soenardi. 2008. Tes Bahasa. Jakarta: PT. Indeks Education Inc.

Gie, The Liang. 2002. Terampil Mengarang. Yogyakarta: Andi Cipta.

Hasan, Iqbal. 2003. Pokok-Pokok Materi Statistik 2. Jakarta: Bumi Aksara.

Hendrikus, Dori Wuwur. 1991. Retorika: Terampil Berpidato, Berdiskusi, Berargumentasi, Bernegosiasi. Yogyakarta: Kanisius.

http://www.unido.org/fileadmin/import/16953_Brainstorming.pdf . diakses pada 10 Desember 2013 pukul 22:34 WIB.

Ismail SM. 2008.Strategi Pembelajaran Agama Islam Berbasis PAIKEM, Semarang: Rasail Media Group.

Keraf, Gorys. 2010. Argumentasi dan Narasi. Jakarta; PT Gramedia.

Kosasih, E. 2003. Kompetensi Ketatabahasaan dankesusastraan Cermat Berbahasa Indonesia. Bandung: CV. Yrama Widya.

Malik, Abdul dan Isnaini leo shanty. 2003. Kemahiran Menulis. Pekanbaru: Unri Press.

Mc Mahan, E, Day, S dan Funk,R. 1993. Literature and The Writing Process. New York: Mc Millan.

Melvin. Silberman.2006. Active Learning 101 Cara Belajar Siswa Aktif.Bandung: Nusa Media. Mulyati, Yeti. 2012. Bahasa Indonesia. Tanggerang Selatan. Universitas Terbuka.

Nasution, 1995.Didaktik Asas-asas Mengajar. Bandung: Jemmars.

Nurgiyantoro, Burhan, 2010. ,PenilaianPembelajaran Berbahasa Berbasis Kompetensi, Yogyakarta,BPFE .

Nursisto. 2009. Menuntun Mengarang. Yogyakarta: Adicita.

Pidarta, I Made, 2000, LandasanPendidikan , Jakarta, Rineka Cipta. 
Purwanto, Ngalim. 2010. Prinsip-Prinsip dan Teknik Evaluasi Pengajaran. Bandung: PT. Rosdakarya.

Riauwati.2009. Berbahasa Indonesia yang Baik dan benar.Tanjung pinang: Umrah Pres.

Richards, Jack C. 2008. Teaching Listening and Speaking From Theory to Practice. London: Cambridge University Press.

Roestiyah N.K, 2008. Strategi Belajar Mengajar. Jakarta: PT Rineka Cipta.

Santoso , Ardi. 2004. Menang Dalam Debat. Semarang: Elfhar.

Semi, M Atar. 2007. Dasar-dasar Keterampilan Menulis. Bandung: Percetakan Angkasa.

Slameto.2008. Belajar Dan Faktor-Faktor Yang Mempengaruhinya. Jakarta: PT. Rineka Cipta.

Subari, Andi, 2002. Seni Negoisasi. Jakarta: Efhar.

2003. Debat sebagai Retorika. Semarang: Aneka Ilmu.

Sudjana. 2005. Metoda Statiska Edisi ke-6. Bandung: Tarsito.

Sudjana, Nana. 2005. Penilaian Hasil Proses Belajar Mengajar. Bandung: PT Remaja Rosdakarya.

Sugiyono.2009. Metode Penelitian Kuantitaif dan Kualitatif.Bandung : Alfabeta.

Suriamiharja Agus, dkk. 1996. Petunjuk Praktis Menulis. Jakarta: Depdikbud.

Sutopo, Sungkono. 2001. "Pendekatan Terpadu dalam Pengajaran Bahasa dan Sastra Indonesia”. Komposisi (Jurnal Pendidikan Bahasa Sastra dan Seni) II. 1:64-65. Padang: FBSS Universitas Negeri Padang.

Tarigan, Djago dkk. 2005. Pengembangan Keterampilan Berbicara. Bandung: Angkasa.

Tarigan, Henry Guntur. 2004. Menulis.Bandung: Angkasa Bandung.

........, 2008. Berbicara Sebagai Suatu Keterampilan Berbahasa. Bandung: Angkasa.

Wagiran dan Mukh Doyin. 2005. Curah Gagasan. Semarang: Rumah Indonesia.

Wina Sanjaya. 2009. Strategi Pembelajaran Berorientasi Standar Proses Pendidikan. Jakarta. Prenada Media Group.

Wiyanto, Asul. 2000.Terampil Diskusi. Jakarta: Gramedia Widiasarna Indonesia.

Yamin, Martinis. 2007. Strategi Pembelajaran Berbasis Kompetensi. Jakarta: GP Press.

Yunus, Abidin. 2009. Pembelajaran Bahasa Berbasis Pendidikan Karakter.Bandung: PT. Refika. 